\title{
Study of Business Japanese Teaching Reform
}

\author{
Jing Zhang ${ }^{1}$ \\ ${ }^{1}$ Xi'an University, Xi'an, Shaanxi, 710065
}

Keywords: Business Japanese; teaching reform; talent training

\begin{abstract}
Business Japanese is characterized by practicality and application. Correspondingly, business Japanese teaching should also focus on the cultivation of practical and applied skills. With the continuous deepening of the business Japanese teaching reform, the construction of an integrated practical teaching system serving the training objectives of professional talents has become an urgent issue for research and practice. This paper studies and discusses the construction of business Japanese practical teaching system based on the experience of other professional teaching.
\end{abstract}

\section{Introduction}

Business Japanese, developed from the Japanese language for foreign trade, is a comprehensive course that combines Japanese and business knowledge. It aims to develop high-quality, composite Japanese talents who are both proficient in Japanese and have business knowledge. From the late 1980s to the early 1990s, business Japanese began to appear in domestic universities [1]. After more than 20 years of development, most colleges and universities have set up business Japanese courses. The establishment of the International Business Japanese Research Committee of the China Institute of International Trade in 2007 marked the further standardization and systematization of business Japanese teaching in China. China has already replaced the United States as Japan's largest trading partner. It can be expected that the market's demand for business Japanese talent will continue to increase. How business Japanese courses seize opportunities and meet challenges has become an issue that we urgently need to seriously consider.

\section{The Status Quo and Existing Problems of Japanese Education}

In response to changes in market demand for Japanese language talent, from July 2009 to November 2010, we conducted field trips to eight universities in Dalian, and conducted Japanese language professional development and personnel training models with Japanese language professionals in various universities. The related issues were discussed, and 43 professional teachers in our Japanese language department were also surveyed for relevant information on business schools. At the same time, a special survey of 78 specialties of 59 colleges and universities in and outside the province has been conducted through the Internet. The survey found that $46 \%$ of the Japanese undergraduate majors are Japanese language and Japanese language literature. The curriculum is basically the same, $35 \%$ of the schools are in the direction of economic and trade Japanese, and others are in the direction of IT Japanese. The professional orientation and curriculum of these universities reflect the problems existing in the traditional Japanese talent training model. That is to say, it is the students' language ability that they pay attention to, and they ignore the application of language. From curriculum setting to teaching methods and training models, they all tend to be research-oriented. Teaching and practical applications are seriously out of touch with business needs and social needs. In 2010, the author participated twice in the "2010 Japanese Higher Vocational College and Business Japanese Teaching Seminar” held in Beijing and Shanghai by the Ministry of Education's Higher Vocational College Language Teaching Programs. . Participants shared the same view on the current contradiction between the Japanese language training model and business needs and social needs. Although everyone did not do the same, they were all trying hard to find a way out and correct their professional training direction. Many 
colleges and universities have already begun to transition to training application-oriented talents according to market demand. Some higher vocational colleges are one step ahead and are dedicated to training business Japanese talents. However, due to the lack of thorough understanding of the concept of business Japanese language, the lack of overall supporting curriculum and the construction of supporting materials, and the lack of a practical curriculum system that can reflect students' integrated learning, the training of Japanese for business personnel is still in the initial stage of reform.

\section{Business Japanese Teaching Reform}

The curriculum reform of Business Japanese is a systematic project. It includes reflection on teaching objectives, improvement of teaching content, updating of teaching methods, enrichment of teaching methods, and strengthening of cooperation between schools and the community. The core of the reform is the reform of teaching and evaluation [3].

As a highly practical curriculum, the focus of business Japanese teaching should be to develop students' Japanese communication skills and business practice skills. Objectively speaking, the Japanese language ability and business practice ability of Chinese college students are still relatively weak. Many teachers conducted various explorations for this purpose and proposed teaching methods suitable for business Japanese, such as "Project Law", "Case Law", and "Segmented Communicative Teaching of Scenes". Their common features are: It tries to change the "teaching" and "exercise" model of teacher-centered teaching in the traditional Japanese language teaching, and creates a classroom teaching pattern that takes students as the main body and practices as the direction. The author believes that business Japanese is a foreign language first, and it is entirely possible to use the characteristics of foreign language teaching methods to improve students' communication skills. Because, "Foreign language teaching method is to study the science of imparting and learning foreign languages. The quality of foreign language teaching methods directly affects the improvement of foreign language teaching quality". In English teaching, people often talk about foreign language teaching. In Japanese teaching, the discussion of this issue is limited to Japanese and foreign Japanese and public Japanese. Few people talk about the application of foreign language teaching in business Japanese.

The communicative approach is a school of pedagogy aimed at conveying one's wishes and emotions to each other [4]. It came about in the 1970s. It emphasizes the importance of language practice in real situations, "putting the language into a certain context, and cultivating practical communicative skills. Even in the classroom, teachers need to imagine the actual scene in real life and consider the wording of communication. And through the exchange to achieve the purpose of ", etc." Students like this interactive form of teaching. It includes various types of role-playing, task exercises, games, etc., and role-playing is the most popular. Role play is a commonly used method in foreign language teaching. For students who study business Japanese, they rarely have the opportunity to participate in actual business activities. The role-playing just makes up for this shortcoming. It is an effective means for business Japanese learners to practice conversations. The teacher's guidance can be divided into four basic steps: selection of scenarios and roles, prior preparation, on-site guidance, and subsequent evaluation. You can choose different business activities as role play scenarios. Teachers can create some role cards, indicate the contents of the roles to be played by different students, as well as the content of the conversation, the grammar and sentence patterns used, etc. Students can write in Chinese, which can help students choose their own characters. In the process of student role-playing, teachers should remind students to consciously use the expression of their identity. In the subsequent evaluation stage, teachers should not pay too much attention to the students' mistakes, so as not to undermine students' self-confidence, causing them not to undertake similar role-playing in the future [5]. The focus of the follow-up assessment is to solicit students' opinions and opinions on the role-playing activities, and to obtain relevant information in the form of evaluation questionnaires or questionnaires.

The teaching activities are very complicated. There is no teaching method that can cover everything. Therefore, the teaching method should also be pluralistic. Effective teaching should be 
the process of optimization and combination of various teaching methods. For business Japanese language teaching, in addition to using communicative methods to cultivate students' communicative competence, it is also possible to use other foreign language teaching methods flexibly according to specific circumstances, such as community language learning. This method was produced in the United States in the 1960s and is mainly used for foreign language teaching. It has two outstanding features: First, it is student-centered and teaches obedience. Teachers act as counselors and assistants to help students communicate. The second feature is that students use their mother tongue to communicate and gradually transition from the student's mother tongue to a foreign language. You can use the community language learning method at the time of free discussion. For students who are not yet able to communicate fluently in Japanese, this method can promote the exchange of opinions among students. In short, understanding the strengths and weaknesses of various foreign language teaching methods, avoiding weaknesses, and forming one's own teaching style can achieve good results in cultivating students' interpersonal skills.

In fact, for business Japanese learners, they are concerned about whether they can use proper language for business communication in the future and whether they can use this language tool to lay a foundation for business success. According to the author's observation, students have little interest in grammar and vocabulary skills. In the evaluation of teaching, this feature should be taken into consideration. The focus of the evaluation should not be on whether students are acquainted with the contents of textbooks, whether they have improved pronunciation, and whether they can use grammar correctly. Instead, it should be placed on students' practical ability. It is possible to set such a benchmark "What the student learned compared to before." For this purpose, a sub-assessment approach can be used. The first is to test the bottom to understand the students' starting level. Specifically, you can judge by reading the press release. Followed by classroom observation. In the dialogue between the students and the students, observe whether the expression is natural, whether the language meets the general social norms, and the content of the answer is very exciting. The last is the exam. There are two ways to choose the exam. The first is the score test. You can predict the scope and time of the questions to determine how much knowledge the student has mastered. The common test method is role play. The second is the level test. Do not prompt the scope of the exam to determine actual work ability. In addition, teaching evaluation is not to give a simple score to determine the degree of students' knowledge and skills, but should be to improve teaching. "Evaluation for improvement" places great emphasis on the teaching process. For example, if we find that students have unnatural expressions in classroom observation, we should promptly analyze the causes of the mistakes and correct them. For example, the cause of the error is whether it is caused by insufficient knowledge, or is caused by the influence of the mother tongue, or because of an oral error that is not noticed. Gradually shifting from focusing on the results of classroom teaching to focusing on the classroom teaching process will be the development direction of future business Japanese teaching evaluation. In order to ensure the smooth implementation of the training course system, we have planned and organized young teachers of our department by hiring outside experts and senior corporate personnel to attend school lectures, practical training on campus, and exchanges between Chinese and Japanese teachers with rich teaching experience. Various training activities centered on practical training methods were carried out. Among them, several training activities related to Japanese language teaching; several technical trainings oriented to employment orientation; several corporate training related to enterprise needs and corporate culture; and several other comprehensive trainings. They have sent two teachers to the company to teach, to understand the needs of the front line (enterprise), thereby enhancing the teachers' own practical ability and practical training techniques, and ensuring the smooth progress of practical training.

\section{Conclusion}

Business Japanese is still a young course in China. It needs constant research and exploration in the aspects of theory promotion, teaching practice, and teacher construction. The society puts forward higher requirements for the cultivation of business Japanese talents. How to develop more 
perfect teaching materials, how to allow students to have a greater degree of improvement in their business Japanese practice ability within the limited teaching time, and how to promote students' enthusiasm for learning through evaluations, These issues are worth our further consideration.

\section{References}

[1] Yan Hongjun. On the definition of business Japanese language ability. Japanese language learning and research [J]. 2011, (3): 61.

[2] Li Aiwen. History, current situation and future prospects of Chinese business Japanese education. Japanese language learning and research [J]. 2011, (4): 8.

[3] Wu Lingen. Construction of university practical teaching system in the context of popularized higher education. Higher Education Forum [J]. 2004, (6): 101.

[4] Zhang Yuping, et al. On the undergraduate practice teaching system of research universities. Laboratory research and exploration [J]. 2005, (3): 67.

[5] Zhang Yijuan. 2006. The application of non-verbal communication in cross-cultural business communication - A new attempt in business Japanese teaching [J]. Japanese Language Learning and Research (1). P: 53-56 